\title{
Relative susceptibility of Crotalaria spp. to attack by Etiella zinckenella in Puerto Rico'
}

\author{
Alejandro E. Segarra-Carmona and Pedro Barbosa ${ }^{2}$
}

\begin{abstract}
Four Crotalaria species were found attacked by the lima bean pod borer Etiella zinckenella (Treit.) in Puerto Rico: $C$. pallida, C. anagyroides, $C$. zanzibarica and $\boldsymbol{C}$. incana. Non-susceptible species were $\boldsymbol{C}$. retusa, $\boldsymbol{C}$. stipularia and $C$. lanceolota. Early literature observations on the effect of soil characteristics ( $\mathrm{pH}$, soil peneirability, and organic matter) on attack rates of this borer to $C$. pallida could not be confirmed on the basis of field observations. Only plant patch size seemed to be positively correlated with attack rates. Female oviposition patterns are discussed. Oviposition on $C$. pallida field collected pods was restricted to green pods larger than 3.2 $\mathrm{cm}$. No eggs were found on senescent pods.
\end{abstract}

\section{INTRODUCTION}

The lima bean pod borer, Etiella zinckenella (Treit.), was reported in Puerto Rico in 1890 (20). Since then, it has been studied by many visiting and resident entomologists. Leonard and Mills (6) first reported this pyralid boring on pods of lima beans, cowpeas, pigeon peas and Crotalaria (no species given). Wolcott $(17,18)$ recorded that among all species of Crotalaria, only C. incana $\mathrm{L}$. was attacked, and C. retusa $\mathrm{L}$. appeared immune to this borer. This author also reported that Crotalaria plants growing on sandy soils were more susceptible to pod loss by $E$. zinckenella than those growing on clay soils. Further studies by Scott (12) corroborated Wolcott's observations on C. retusa resistance and added.C. stipularia Desv. to the list of resistant species. Since then no other studies have been conducted on the distribution or susceptibility of Crotalaria species to this insect pest, even though the number of newly introduced species has steadily increased in Puerto Rico.

The importance of Crotalaria species as key alternate hosts of legume pest populations has been established (5). In Australia, outbreaks of Etiella behrii and $E$. zinckenella on grain legumes are determined by buildups of Crotalaria populations (14). The aim of the present article is to determine the susceptibility of the most common Crotalaria species in Puerto Rico; review some early observations about habit-caused plant

'Manuscript submitted to Editorial Board 16 June 1987.

${ }^{2}$ Assistant Entomologist, Department of Crop Protection, Agricultural Experiment Station, Univ. P. R., Rio Piedras, P. R. 00928; and Rrofessor of Entomology, Department of Entomology, University of Maryland, College Park, Md. 20742, despectively. 
susceptibility; study the oviposition habits of $E$. zinckenella on its preferred host, Crotalaria pallida; and suggest the possible advantages of Crotalaria population regulation as a management tool.

\section{MATERIALS AND METHODS}

Field surveys of Crotalaria species were conducted by driving and/or walking in early successional areas from 1980 to 1983. More than 12,000 road miles were covered. Once a Crotalaria patch was discovered, plants were checked for the presence of $E$. zinckenella. Species identity was determined by the senior author. Soil samples were taken from all Crotalaria pallida (Ait.) sites in $1980(n=15)$. Sites were named according to township and road number. Soil characteristics such as relative patch size, soil pH, percentage organic matter, and penetrability (using soil penetrometer) were recorded. Relative patch size was established by ranking sites from 1 to 5 , where 5 represented the largest patches. Attack rates were determined by examining pod raceme samples. Sample size varied from patch to patch according to pod availability. In small patches, all available pods were collected, whereas in larger patches 1520 mature racemes were sampled. Number of pods per raceme and number of infested pods were determined. Each factor was then correlated with $E$. zinckenella pod attack rates. Determination of pod size selection for oviposition was accomplished by collecting and carefully inspecting pods of all sizes for the presence of eggs. Each pod with eggs was measured longitudinally with a Vernier caliper and recorded. The number of eggs per pod was also noted.

\section{RESULTS AND DISCUSSION}

Crotalaria species susceptibility to $E$. zinckenella. Crotalaria species were found growing virtually in all but the drier districts of the southwestern part of the island (table 1). All species were found restricted to recently disturbed sites, roadsides or river banks. Of the nine Crotalaria species mentioned by Martorell et al. (9), seven were found in our survey.

TABXE 1.-Relative susceptibility of Crotalaria species to E. zinckenella

\begin{tabular}{lccccc}
\hline \multicolumn{1}{c}{ Species } & $\begin{array}{c}\text { Relative } \\
\text { abundance }\end{array}$ & \multicolumn{3}{c}{ Elevation } & Susceptibility \\
\cline { 3 - 6 } C. pallida & +++ & Low & Mid & High & \\
C. incana & ++ & + & + & + & Yes \\
C. anagyroides & tr & + & + & + & Yes \\
C. zanzibarica & + & + & - & - & Yes \\
C. relusa & ++ & + & + & - & Yes \\
C. stipularia & + & + & + & + & No \\
C. lancelala & ++ & - & + & - & No \\
C.juncea & tr & - & + & + & No \\
\hline
\end{tabular}

' Not available beeause of small sample. 
These species were C. pallida Ait., C. retusa L., C. incana L., C. stipularia Desv., C. zanzibarica Benth., $C$. anagyroides HBK., $C$. juncea L., and an additional, previously unreported species, C. lanceolata L.

Of the eight species sampled, four were attacked by $E$, zinckenella: C. pallida, C. incana, C. anagyroides and C. zanzibarica. Samples of the four species listed above revealed a $20-40 \%$ pod attack, which approximates figures given by Wolcott (16) for C. incana. Crotalaria juncea status as a host plant remains uncertain because only two pods could be examined. Evident from comparisons with early literature, is the enrichment of Crotalaria species on the island. This enrichment has probably enhanced the alternate host spectrum of $E$, zinckenella. For example, Britton and Wilson (1) record only two of the susceptible species $(C$. incana and C. pallida $=$ mucronata Desv. $=$ striata DC). Crotalaria pallida, at present the most abundant species, was regarded as rare and local near the town of Bayamón. Also of interest is the lack of mention of $C$. pallida as a host on early reports of $E$. zinckenella by early authors $(7,14,2,17)$. This could reflect not only the recent invasion by this species, but also the speed at which invasion is possible for some of the recently arrived species.

Patch size and soil characteristics and their effect on Crotalaria susceptibility to E. zinckenella attack

Oviposition patteras on Crotalaria pods.

No significant correlations were obtained between the percentage of pods bored and soil penetrability, $\mathrm{pH}$ or percentage of organic matter. Wolcott (17) noted that plants growing on sandy soils were apparently more susceptible to attack than those growing on heavy clay soils (table 2). Fifteen C. pallida patches were surveyed including sandy, calcareous and clayey soils. Nevertheless, no soil effect was found among the examined variables, thus failing to support Wolcott's conclusions. The only variable measured with high correlations to attack rates was patch size $(r=0.75, p<0.05)$.

Crotalaria pallida pods examined revealed a clear pattern of oviposition preferences related to size and maturity. Eggs were found only on pods larger than $3.2 \mathrm{~cm}$ in length (examined pods ranged from 0.5 to 4.5 $\mathrm{cm})$. Of 1717 pods examined, only $109(6.3 \%)$ contained eggs. A sizable proportion of these (20\%) had more than one egg, with seven being the maximum number found on one pod. The mean length of a newly oviposited pod was $3.94 \pm 0.04 \mathrm{~cm}$ (SE). Apparently, E. zinckenella females place their eggs on a specific pod size which could signal proper pod quality. In the field, pods smaller than $3.0 \mathrm{~cm}$ were prone to premature abscission. The choice of a pod with a lower probability of abortion would be of adaptive value for an internal pod feeder like $E$. zinckenella. 
TABI.E 2. Sorl characteristies of Crotalaria pallida patches infested by Etiella ginckenella, June-Juhy 1980

\begin{tabular}{lcccccc}
\hline Location & $\begin{array}{c}\text { Soil } \\
\text { pentrability }\end{array}$ & $\mathrm{pH}$ & $\begin{array}{c}\text { Organic } \\
\text { matter }\end{array}$ & $\begin{array}{c}\text { No pods } \\
\text { examined }\end{array}$ & Bored & $\begin{array}{c}\text { Size } \\
\text { rank }\end{array}$ \\
\hline Arecibo 129 & & & $\%$ & & $\%$ & \\
Añasco 109 & 4.00 & 8.5 & 2.7 & 435 & 52.1 & 4 \\
Añasco 108 & 0.62 & 6.3 & 0.5 & 145 & 52.6 & 3 \\
Aguada 110 & 2.25 & 6.4 & 1.8 & 87 & 12.5 & 2 \\
Hatillo 2 & 1.25 & 7.8 & 5.5 & 263 & 49.9 & 2 \\
Playa Jobos & 0.28 & 8.7 & 2.1 & 230 & 40.4 & 3 \\
Isabela & 0.25 & 8.2 & 6.5 & 143 & 42.6 & 5 \\
Las Marías & 0.26 & 8.3 & 7.1 & 202 & 33.6 & 2 \\
Las Marías 2 & 3.48 & 7.2 & 0.7 & 52 & 7.1 & 1 \\
Marican 105 & 3.00 & 5.9 & 2.5 & 284 & 18.3 & 2 \\
Lares 129 & 1.27 & 8.2 & 2.1 & 172 & 23.5 & 1 \\
Mayagüez 106 & 3.07 & 5.4 & 1.4 & 127 & 0.0 & 1 \\
San Sebastian 433 & 3.22 & 7.8 & 0.6 & 183 & 34.2 & 2 \\
Yauco 128 & 3.24 & 4.7 & 2.1 & 248 & 92.3 & 5 \\
Villalba & 1.58 & 5.6 & 1.9 & 223 & 18.3 & 3 \\
\hline
\end{tabular}

'Average of five measurements with penetrometer, scale 0-4, where 4 is the hardest soil.

${ }^{2}$ Patches were ranked from smallest (1) to largest (5).

No eggs were found on mature (brown) pods. Singh and Dhooria (10) found that pods which were too hard to be entered successfully resulted in heavy mortality among newly hatched larvae. Mature C. pallida pods are appreciably harder and tougher than green pods, perhaps causing similar mortality. More laboratory tests of this mortality factor are still needed to ascertain its importance. If such an effect is demonstrated, a window of pod vulnerability to $E$. zinckenella could be proposed, dictated at one end by pod abortion and at the other by pod hardness. Such a fixed vulnerability window could pose a formidable obstacle to searching females, especially when pods are scarce, such as during dry seasons in Puerto Rico.

On different Crotalaria species, eggs were found in different places. In the glabrous podded species $C$. pallida, $C$. anagyroides and $C$. zanzibarica the eggs were normally laid under flower sepals; in the pubescent $C$. incana, the eggs were mostly found on pod hairs. This confirms for Crotalaria, species what Hattori and Sato (3) demonstrated on laboratory trials on soybeans: that hairs or their lack trigger females to choose different sites for oviposition.

\section{CONCLUSIONS}

The importance of alternate host plants in the survival of herbivore pest populations and their parasitoids has been well established (11). In some systems, alternate hosts reduce the risks inherent to food supply 
unpredicitability. Should a primary food supply become limiting, an alternate source would provide food and shelter (17). The result is a more stable herbivore population, stabilized by each addition of a host plant species (4). In the seasonal tropics, as well as in temperate zones, a succession of host plants with overlapping phenologies helps pests obtain refuge at any given time of their growing season, enhancing their survival (9). Some authors have suggested the elimination of alternate hosts as a pest management tool $(5,6,8,13)$. The same approach is applicable to E. zinckenella populations. In the Philippines, feral Cajanus cajan L. is responsible for Etiella zinckenella outbreaks on nearby soybean plantations (8). In Australia, Crotalaria spp. act similarly as alternate species (14). In Puerto Rico, the presence of Tephrosia sp. close to pigeon peas significantly increased pod infestation (2). It seems clear that as local populations and diversity of Crotalaria species increase with the increase of deforested areas, wastelands and road sides, Etiella zinckenella populations will enjoy similar population increases on the Island. However, much information is needed before suggesting elimination of feral Crotalaria populations near legume fields. Their impact in the maintenance of the borer's natural enemies should be weighed against their negative influence.

\section{RESUMEN}

Susceptibilidad de Crotalaria spp. a Etiella zinckenella en Puerto Rico

Un reconocimiento de especies de Crotalaria determinó la susceptibilidad de cuatro especies al ataque del barrenador Etiella zinckenella (Treit.): C. pallida, C. anagyroides, $C$. zanxibarica y $C$. incana. No se hallaron atacadas las especies $C$. retusa, $C$. stipularia o $C$. lanceolata. No se logró corroborar algunas observaciones informadas en la bibliografía sobre el efecto de los suelos sobre la intensidad del ataque del barrenador a $C$. pallida. Solo la densidad de plantas resulfó positivamente correlacionada con la severidad del ataque. Se observó que la postura de huevos está restringida a vainas verdes de Crotalaria pallida de más de $3.2 \mathrm{~cm}$. No se hallaron huevos en vainas senescentes.

\section{LITERATURE CITED}

1. Britton, N. L. and P. Wilson, 1923-1930. Botany of Porto Rico and the Virgin Islands, descriptive Flora. Spermatophy. Sci. Surv. P. R. and the Virgin Islands. N. Y. Acad. Sci. 5: 1-663.

2. Cruz, C., 1975. Observations on the pod borer oviposition and infestation of pigeon pea varieties. J. Agric. Univ. P. R. 59: 63-8.

3. Hattori, M. and A. Sato, 1982. Substrate factors involved in oviposition response of the lima bean pod borer, Etiella zinckenella Treitshke (Lepidoptera: Pyrtidae). Appl. Entomol. Zool. 18; 50-6.

4. Jones, W. A. and M. J. Sullivan, 1982. Role of host plants in population dynamics of stink bug pests of soybean in South Carolina. Environ. Entomol. 11: 867-75.

5. Kogan, M., 1981. Dynamics of insect adaptations to soybean: Impact of integraled pest management. Environ. Entomol, 10:363-71. 
6. Leonard, M. D. and S. A. Mills, 1931. A preliminary report on the lima bean pod borer and other legume pod borers in Porto Rico. J. Econ. Entomol. 24: 466-73.

7. Litsinger, J. A., C. B. Quirino, M. D. Lumaban and J. P. Bandong, 1978. The grain legume pest complex of rice based cropping systems in the Philippines. In: Pests of grain legumes: Ecology and Control. Eds, S. R. Singh, H. F. Van Emden and T. A. Taylor. Academic Press, N. Y.

8. Malavasi, A. and J. S. Morgante, 1981. Adult and larval populations of Anastrepha fraterculus and its relationship to host availability. Environ. Enzlomol. 10: 275-78.

9. Martorell, L. F., A. H. Liogier and R. O. Woodbury, 1981. Catálogo de los nombres vulgares y cientificos de las plantas de Puerto Rico. Bol. 262, Esta. Exp. Agric. Univ. P. R.

10. Singh, H. and M. S. Dhooria, 1971. Bionomics of the pea pod borer, Etiella ainckenella (Treitschke). Indian J. Entomol. 33: 123-30.

11. Seott, L. R., 1940. The bean pod borers in Puerto Rico. J. Agric. Univ. P. R. 24: 35-47.

12. Tulner, J. W., 1978. Pests of grain legumes and their control in Australia. In: Pests of grain legumes: Ecology and Control. Eds, S. R. Singh, H. F. van Emden and T. A. Taylor, 454 pp. Academic Press, N. Y.

13. van Driesche, R. G., 1983. Meaning of "Percent Parasitism" in studies of insect parasitoids. Environ. Entomol. 12: 1611-22.

14. Wint, W., 1983. The role of alternative host-plant species in the life of a polyphagous moth, Operophtera brumata (Lepidoptera: Geometridae). J. Anim. Ecol. 52:439-50.

15. Wolcott, G. N., 1933. The lima bean pod borer caterpillars of Puerto Rico. J. Agric. Univ. P. R. 17: 241-55.

16. - 1934. Lima bean pod borer caterpillars of Puerto Rico on their wild hosts. $J$. Agric. Univ. P. R. 18: 429-34.

17. — 1948. The insects of Puerto Rico. J. Agric. Univ. P. R, 32: 1-975. 